\title{
Synthetic cannabinoids as a cause for black carbonaceous bronchoalveolar lavage
}

\author{
Abhishek Biswas, ${ }^{1}$ Vipul Patel, ${ }^{2}$ Michael Jantz, ${ }^{1}$ Hiren J Mehta ${ }^{1}$
}

'Department of Pulmonary, Critical Care and Sleep Medicine, University of Florida, Gainesville, Florida, USA ${ }^{2}$ Department of Pulmonary and Critical Care Medicine, Saint Joseph Heart and Lung Institute, Phoenix, Arizona, USA

\section{Correspondence to}

Dr Hiren J Mehta

Hiren.Mehta@medicine.ufl.edu

Accepted 21 June 2015

\section{DESCRIPTION}

A 44-year-old woman with HIV (non-compliant to therapy), atypical mycobacterial infection and pneumocystis infection in the past, presented with subacute fever of 5-day duration. She also had a cough with productive yellow sputum that gradually turned into a dry cough. Physical examination was consistent with bilateral rhonchi and wheezes. She was an ex-smoker who had quit 10 years earlier, but was a current cocaine and cannabis abuser. Chest $\mathrm{X}$-ray showed airway opacities on the right middle zone suggestive of pneumonia (figure 1). A CT scan of the chest showed scattered right middle lobe

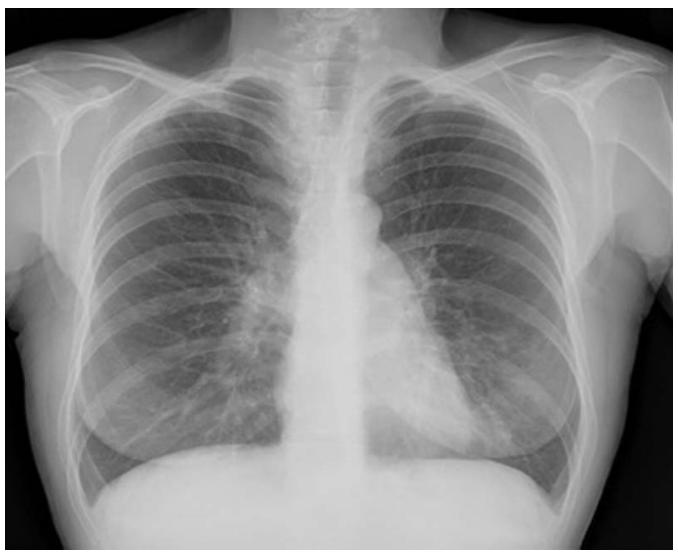

Figure 1 Chest $X$-ray showing airspace disease in the lower zones bilaterally.

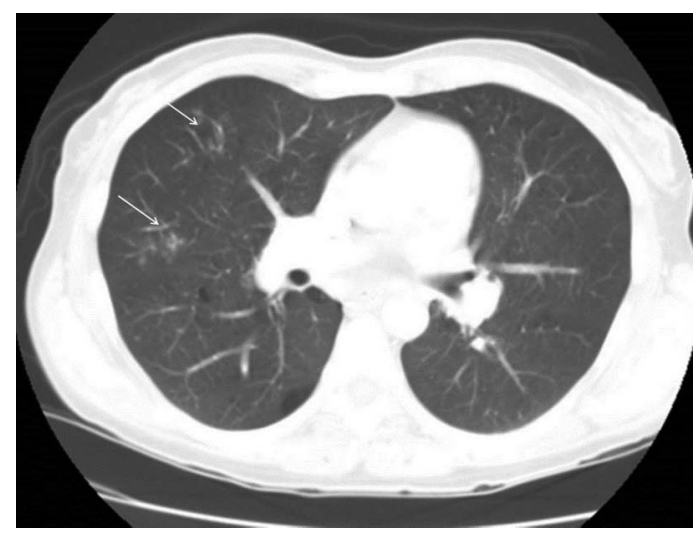

Figure 2 CT of the chest demonstrates ground glass, nodular opacities in the right upper lobe anteriorly (marked with arrows). nodular opacities (figure 2). Differential diagnosis included Pneumocystis jiroveci pneumonia, tuberculosis, non-tuberculosis mycobacterial infection and fungal infections such as histoplasmosis, cryptococcosis, blastomycosis and lymphoma. The patient's clinical, radiographic and histopathology was consistent with respiratory bronchiolitisassociated interstitial lung disease (RB-ILD).

Bronchoscopy revealed a normal airway, however, the bronchoalveolar lavage fluid was black in colour (figure 3). Transbronchial biopsies were also black. Histopathology revealed extensive intra-alveolar pigment laden macrophages and type 2 pneumocyte hyperplasia devoid of granulomas, eosinophils, malignancy or infection (figure 4).

RB-ILD is a type of idiopathic interstitial pneumonia that is classified as a smoking-related lung disease having the pathological features of respiratory bronchiolitis, clinical symptoms of cough and dyspnoea; high-resolution CT usually shows diffuse

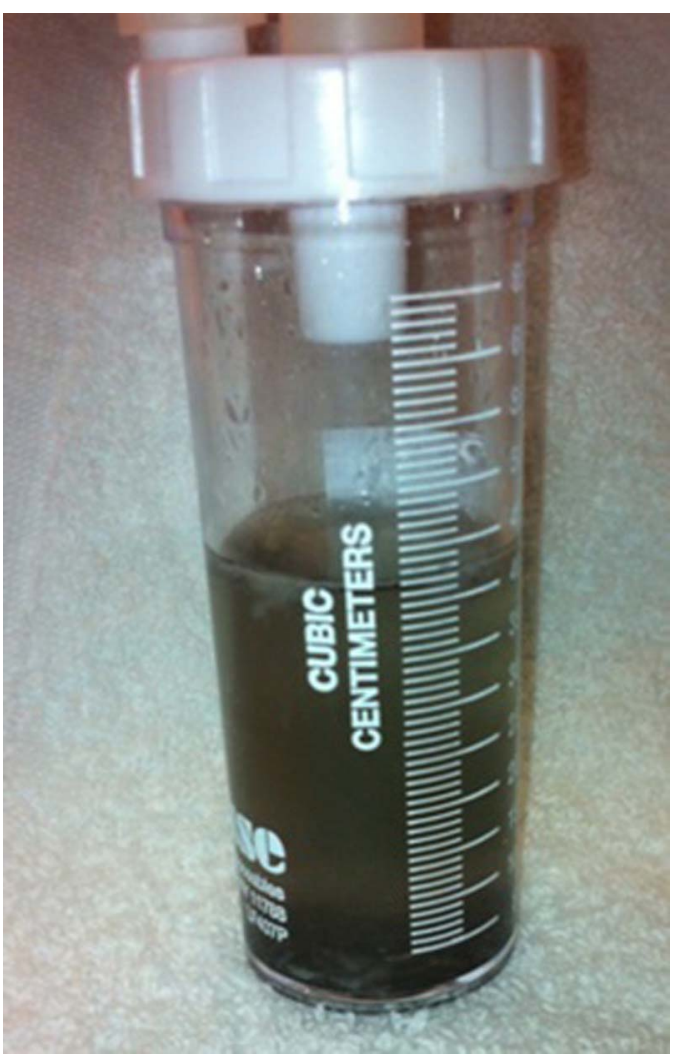

Figure 3 Bronchoalveolar lavage obtained from the lingula shows dark soot-coloured fluid. 


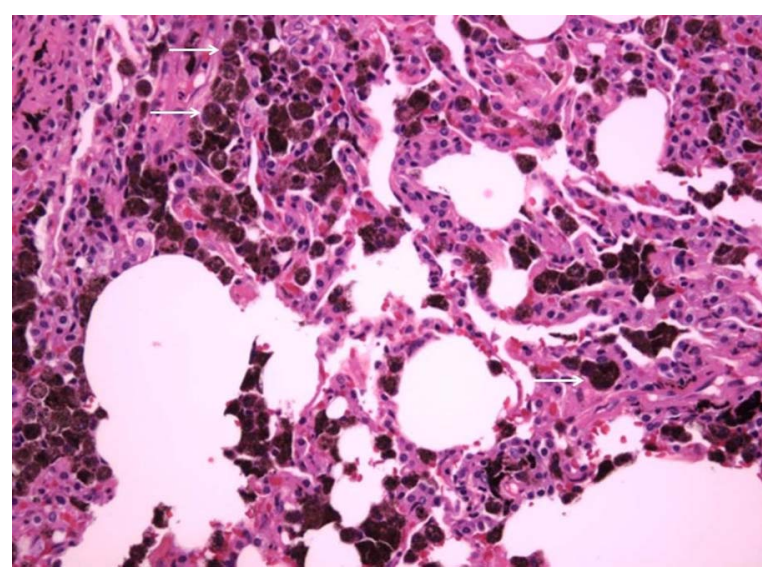

Figure 4 Histopathological examination $(\times 200)$ of lung tissue demonstrates plenty of browning-dark pigmented macrophages (arrows) and type-II pneumocyte hypertrophy and minimal fibrosis. This is classic for respiratory bronchiolitis-interstitial lung disease.

or patchy ground-glass opacities or centrilobular nodules and reticulation. Most often, pulmonary function tests suggest an obstructive pattern or a mixed obstructive and restrictive pattern with decreased diffusing capacity of the lungs for carbon monoxide. Treatment is smoking cessation. The condition is rarely life threatening.

\section{Learning points}

A black bronchoalveolar lavage is classically seen in heavy smokers. ${ }^{1}$

- Pulmonary complications may result from impurities inhaled during the process of cocaine smoking. We propose that synthetic cannabinoids can do the same by a similar mechanism.

- Although a type of interstitial lung disease, a severe degree of lung fibrosis requiring treatment is uncommon. Smoking cessation and, in our case, cessation of cannabis smoking, is the treatment for this condition.

Contributors $A B$ contributed to the study design, data collection and manuscript writing. HJM contributed to the study design, data collection and manuscript writing. VP contributed to the study design, data collection and manuscript writing. MJ contributed to the study design, data collection and manuscript writing.

Competing interests None declared.

Patient consent Obtained.

Provenance and peer review Not commissioned; externally peer reviewed.

\section{REFERENCE}

1 Lynn W, Kylstra J, Sahu S, et al. Investigations of black bronchoalveolar human lavage fluid. Chest 1977;72:483-8.

Copyright 2015 BMJ Publishing Group. All rights reserved. For permission to reuse any of this content visit http://group.bmj.com/group/rights-licensing/permissions.

BMJ Case Report Fellows may re-use this article for personal use and teaching without any further permission.

Become a Fellow of BMJ Case Reports today and you can:

- Submit as many cases as you like

- Enjoy fast sympathetic peer review and rapid publication of accepted articles

- Access all the published articles

- Re-use any of the published material for personal use and teaching without further permission

For information on Institutional Fellowships contact consortiasales@bmjgroup.com

Visit casereports.bmj.com for more articles like this and to become a Fellow 